\title{
Repetitive DNA sequences as probes for phylogenetic analysis in Vicia genus
}

\author{
Frediani M. ${ }^{1, *}$, F. Maggini ${ }^{1}$, M.T. Gelati $^{1}$ and R. Cremonini ${ }^{2}$ \\ ${ }^{1}$ Dipartimento di Agrobiologia ed Agrochimica, Università della Tuscia, via San C. de Lellis, 01100 Viterbo, Italy. \\ ${ }^{2}$ Dipartimento di Scienze Botaniche, Università di Pisa, via L. Ghini 5, 56126 Pisa, Italy.
}

\begin{abstract}
In the process of further characterizing phylogenetic relationships among Vicia species of the subgenus Vicia, four different molecular DNA markers were used: a tandemly repeated DNA sequences about 60 bp in length (FokI), a 336 bp element ( $\mathrm{p} V f 7$ ) homologous to the IGS repeats (but that does not reside in the policistronic rDNA units); a family of repeated DNA sequences (VfB) of about $1200 \mathrm{bp}$ in length (that might be derived from a mobile DNA element) and a family of repeated DNA sequences (VfM) of about $60 \mathrm{bp}$ that can be considered a minisatellitelike sequence (EMBL accession nr. AJ242773). The comparison of the obtained results has enabled the definition of the phylogenetic relationships among the analysed species confirming that $V$. faba, $V$. bitbynica and the species of Narbonensis section, represent three distinct taxonomic groups according to the Maxted's classification (1993). VfB and VfM marker discriminate inside the sect. Narbonensis, too, evidencing a greater affinity between some species.
\end{abstract}

Key words: DNA sequences, phylogenetic relationships, repeated DNA, Vicia.

\section{INTRODUCTION}

The genus Vicia is a member of the legume tribe Vicieae of the Papilionoideae and the genus itself has proved a popular group to study, then being $20 \mathrm{ma}$ jor classifications of the genus since Linneus. BALL (1968) divided the genus into four sections: Vicia, Cracca, Ervum and Faba. Kupicha (1976) recognized 22 sections in the two subgenera Vicia and Vicilla. MAXTED et al. (1991) included two newly discovered species in Vicia sect. Faba: V. kalakhensis Khatt., Maxt. et Bisby (КнаттAв et al. 1988) and V. eristalioides Maxt. (MAXTED 1988); as a consequence, the $V i$ cia sect. Faba comprised three distinct units, two of which were monospecific: $V$. faba L. and $V$. bithynica L., while the third was larger, containing the seven species referred to as the Narbonensis complex: $V$. narbonensis L., V. serratifolia Jacq., V. galilaea Plitm. et Zoh., V. hyaeniscyamus Mout., V. johannis Tamasch., V. kalakhensis Khatt., Maxt. et Bisby and V. eristalioides Maxt. Later MAXTED (1993) proposed a new classification of subgenus Vicia where nine sections were present and the old Faba section was substituted by three distinct sections: Bithynicae and Faba monospecific and Narbonensis which contained the seven species before referred to as the Narbonensis complex.

\footnotetext{
* Corresponding author: fax +39-761-357346; e-mail: frediani@unitus.it.
}

In previous papers, we reported cytological, karyological and biochemical data in order to elucidate the relationships inside Vicia subgenus (CREMONINI et al. 1998 a, b; FREDIANI et al. 1992, 1999; Maggini et al. 1991, 1995; Venora et al. 2000).

In phylogenetic studies, it is important to use as markers a broad set of DNA sequences since more regions of the genome become involved and, consequently, more detailed information can be obtained. A way to gain knowledge about the structure and evolution of plant genomes is to study the organization of repetitive DNA sequences and to examine their conservation or divergence within related species. In this paper we report new experimental evidence based on the use of four different molecular markers belonging to the heterogeneous class of repeated DNA sequences; three of these molecular markers have been previously used to study the structure of the genome of $V$. faba. The first marker we used was FokI, a family of tandemly repeated DNA sequences about $60 \mathrm{bp}$ in length, which represents a considerable portion of the genome of $V$. faba (KAто et al. 1984; Maggini et al. 1995); the second, named $\mathrm{p} V f 7$ repeats, represents another family of repetitive DNA related to sequences founded in Intergenic Spacer (IGS) of ribosomal DNA and spread in centromeric and telomeric regions of $V$. faba (KaTO et al. 1985; MAGgini et al. 1991); VfB represents a family of repeated DNA sequences of about $1200 \mathrm{bp}$ in length which are dispersed in the genome of broad bean and absent or rare only at the hetero- 
chromatic chromosomal regions (FrEdiani et al. 1999). The last marker, termed VfM, is a minisatellite-like sequence isolated in a $V$. faba library.

Minisatellites are relatively short DNA sequences (10-100 bp) repeated in tandem, dispersed throughout the genome. Extreme variability in the tandem repeat copy number of minisatellite loci is considered to be the source of the observed polymorphisms in human (JeFFreys et al. 1985; NAKAMURA et al. 1987) and in a variety of animal and plant species (JeFFreys and Morton 1987; Broun and TANKSLEy 1993; Winberg et al. 1993; Tourmente et al. 1994). Heath et al. (1993) reported a new technique, named Direct Amplification of Minisatelliteregion DNA (DAMD), which uses PCR to direct the amplification of minisatellite-rich regions by using as a single primer the common motif (core sequence) present in the repeats. Indeed it has been speculated that if a portion of a minisatellite array is involved in an inversion this would make PCR possible using a single minisatellite core sequence as a primer. As a consequence, this PCR application is capable of producing RAPD-like results in order to detect polymorphisms among species and cultivars, too.

The reported experimental data have allowed us to get further clarification of the phylogenetic relationships among the Vicia species belonging to the sections Faba, Bithynicae and Narbonensis (MAXTED 1993).

\section{MATERIALS AND METHODS}

Plant materials - The names, source and accession number of Vicia species are listed in Table 1. V. sativa has been used as outgroup.
DNA extraction - Nuclear DNAs were extracted and purified from secondary roots, produced after decapitation of the primary one, as described in MAGGINI et al. (1978).

Preparation of probes FokI, $p \mathrm{Vf7}, \mathrm{VfB}$ and Southern blot bybridization - The isolation and the preparation of the probes have been described previously (MAGgINI et al. 1991; 1995; FrEDiAnI et al. 1999).

Genomic DNAs of all the species reported in $\mathrm{Ta}$ ble 1 were digested to completion with Sau 3 AI (for FokI and pVff hybridizations) and EcoRI (for VfB hybridization) restriction endonucleases (Roche), electrophoresed in $0,8 \%$ agarose gel and blotted on nitrocellulose filters (BA85; Schleicher and Schuell) according to SOUTHERN (1975).

The blots were hybridized with the DNA probes labelled with digoxigenin-11-dUTP (Roche), using a random primed DNA labelling kit (Promega).

Isolation of VfM elements - From a genomic library of Vicia faba (FrEDIANI et al. 1999), a clone containing a tandem array of repeated elements of $60 \mathrm{bp}$ (termed VfM), was isolated. The tandem array of repeated elements was separated by cutting with $\mathrm{BamHI}$ and $\mathrm{HpaI}$ restriction endonucleases, the band recovered and cloned in pUC18 BamHI/SmaI using a Sureclone ligation kit (Pharmacia).

Southern blot hybridizations - Genomic DNA of Vicia faba was digested with different restriction endonucleases (BamHI, TaqI, AluI, Sau3AI, EcoRI, RsaI, and HinfI) fractioned by electrophoresis on $1 \%$ agarose, transferred to nitrocellulose membrane (BA85; Schleicher \& Schuell) and hybridized with VfM labelled with digoxigenin-11-dUTP (Roche) using a random primed DNA labelling kit (Promega).

Table 1 - Accession, source, chromosome number, mean nuclear DNA amount in species.

\begin{tabular}{|c|c|c|c|c|}
\hline Species & Accession & Source & $\begin{array}{l}\text { Chromosome } \\
\text { number }(2 n)\end{array}$ & $\begin{array}{c}\text { DNA amount } \\
\text { 4C (pg) }\end{array}$ \\
\hline V. narbonensis L. & 105786 & $\mathrm{IGV}$ & 14 & $29,10 \pm 0,3 *$ \\
\hline V. eristalioides Maxt. & 877321 & B & 14 & $38,58 \pm 0,5^{*}$ \\
\hline V. galilaea Plitm.et Zoh. & 112018 & IGV & 14 & $26,09 \pm 0,2^{*}$ \\
\hline V. byaeniscyamus Mout. & 112008 & IGV & 14 & $31,24 \pm 0,1 *$ \\
\hline V. johannis Tamash. & 112019 & IGV & 14 & $25,08 \pm 0,3 *$ \\
\hline V. kalakhensis Khatt.\& al. & 867095 & B & 14 & $42,22 \pm 0,4 *$ \\
\hline$V$. serratifolia Jacq. & NAR 121/77 & IPK & 14 & $39,59 \pm 0,4 *$ \\
\hline$V$. bitbynica L. & VIC 303/79 & IPK & 14 & $18,03 \pm 0,2 *$ \\
\hline$V$ faba major L. & 113064 & IGV & 12 & $53,12+$ \\
\hline$V$. sativa $\mathrm{L}$. & VIC 556/73 & IPK & 12 & $9,00^{\circ}$ \\
\hline
\end{tabular}

IGV=Istituto Genetica Vegetale, CNR, Bari, Italy;

$\mathrm{B}=$ Genebank, University of Southampton, U.K.;

IPK=Institute of Plant Genetics and Crop Plant Research, Gatersleben, Germany;

*Venora et al. (2000) and references therein

+ Ceccarelli et al. (1995),

- ReEs et al. (1966). 
Genomic DNAs of all the species of Table 1 were digested with HinfI, fractioned by electrophoresis on $1 \%$ agarose, transferred to nitrocellulose membrane (BA85; Schleicher \& Schuell) and hybridized with VfM labelled probe.

Clone selection - The genomic DNA library was plated and three clones containing DNA sequences homologous to VfM elements were identified by plaque hybridization with the digoxigenin-labelled probe. DNA fragments of positive clones (VfR3, VfR9, and VfR10) were amplified by PCR with T7 and Sp6 primers. PCR products were recovered and subcloned in pUC18 Sma/Bap for sequencing.

DAMD-PCR - Genomic DNAs of the analysed Vicia species were amplified using as a single primer the initial sequence (5'-CCTGTGTAGGGTTGCTTC3') of the 60 bp repeat units. After initial denaturation $\left(5 \mathrm{~min}\right.$ at $\left.94^{\circ} \mathrm{C}\right) \mathrm{PCR}$ was run for 35 cycles $(1$ min at $94^{\circ} \mathrm{C}, 1 \mathrm{~min}$ at $55^{\circ} \mathrm{C}$ and $2 \mathrm{~min}$ at $72^{\circ} \mathrm{C}$ ). PCR reaction was performed using 40 pmole of primer, 100 ng of DNA in the standard conditions. The reaction products were then fractionated on $1.2 \%(\mathrm{w} / \mathrm{v})$ agarose gel for $3-4 \mathrm{~h}$ at $80 \mathrm{~V}$ in $1 \mathrm{xTBE}$ and visualized with ethidium bromide.

\section{RESULTS}

Fig. 1 shows the restriction patterns of genomic DNA of Vicia species after digestion with Sau3 AI restriction endonuclease and hybridization with digoxigenin-labelled tandem arrays of FokI repeats. Substantial hybridization occurs only to the DNA of $V$. faba. FokI sequences hybridized to a minimum extent to the DNA of $V$. narbonensis and even less to the DNA of $V$. sativa; no hybridization signal is detected in similar blots of the genomic DNAs of all the other analysed species.

The restriction patterns of genomic DNA of $V i$ cia species after digestion with Sau $3 \mathrm{AI}$ restriction endonuclease and hybridization with digoxigenin-labelled $\mathrm{p} V f 7$ elements are shown in Fig. 2. A strong hybridization signal is present only on $V$. faba DNA. The analysed repeated elements hybridize only on $V$. sativa and, to a minimum extent, on $V$. narbonensis DNA, but again no hybridization signal is present in the DNAs of the remaining seven species.

Fig. 3 shows the restriction patterns of genomic DNA of all the analysed species after digestion with EcoRI restriction endonuclease and hybridization with digoxigenin-labelled VfB elements. In addition to $V$. faba DNA, signal hybridization is evident in all

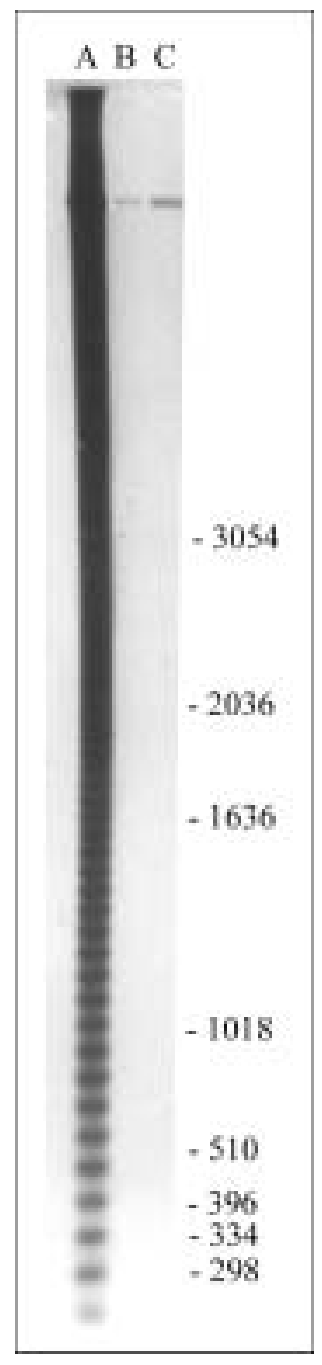

Fig. 1 - Band patterns of genomic DNAs of $V$. faba (A), $V$. sativa (B) and $V$. narbonensis (C) digested with Sau3AI restriction endonuclease after Southern blot hybridization with digoxigenin-labelled FokI repeats. Numerals indicate molecular sizes in base pairs as determined using a 1-kb DNA ladder as a marker.

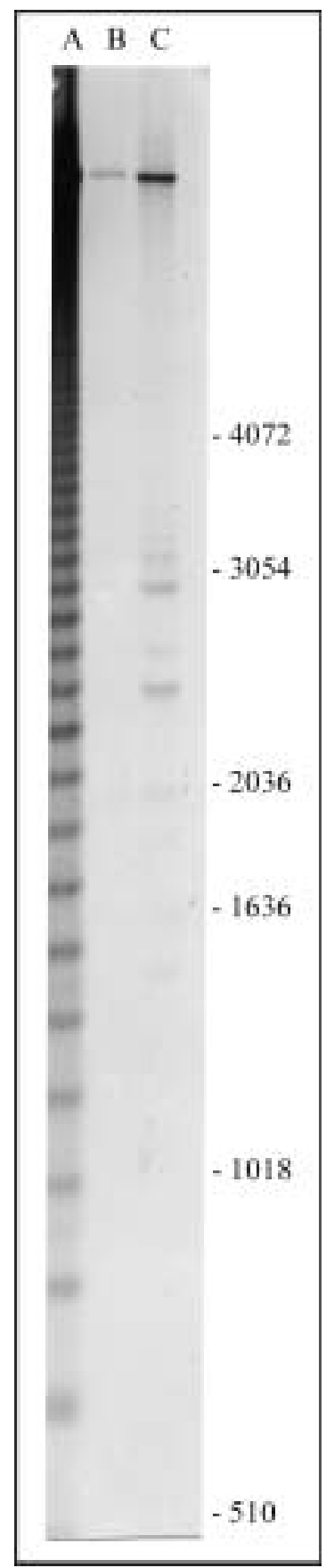

Fig. 2 - Band patterns of genomic DNAs of $V$. faba (A), $V$. narbonensis (B) and V. sativa $(\mathrm{C})$ digested with Sau3AI restriction endonuclease after Southern blot hybridization with digoxigenin-labelled $\mathrm{p} V f 7$ probe. Numerals indicate molecular sizes in base pairs as determined using a $1-\mathrm{kb}$ DNA ladder as a marker. 


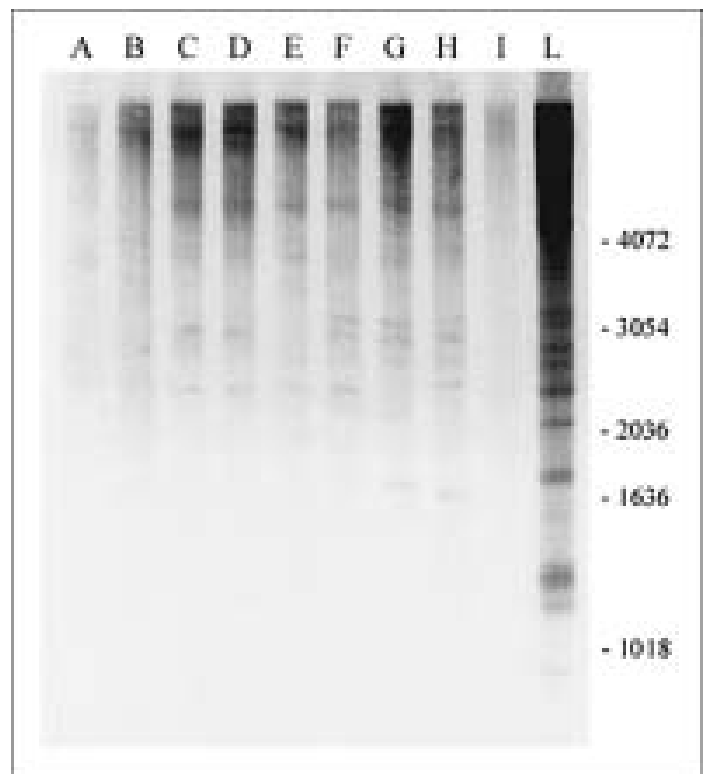

Fig. 3 - Band patterns of genomic DNAs of the analysed species digested with EcoRI restriction endonuclease after Southern blot hybridization with digoxigenin-labelled VfB probe. Numerals indicate molecular sizes in base pairs as determined using a $1-\mathrm{kb}$ DNA ladder as a marker.

$\mathrm{A}=V$. sativa $; \mathrm{B}=V$ serratifolia $; \mathrm{C}=V$. johannis; $\mathrm{D}=V$. byaeniscyamus; $\mathrm{E}=V$. galilaea $\mathrm{F}=V$. kalakbensis; $\mathrm{G}=V$. narbonensis; $\mathrm{H}=V$. eristalioides $; \mathrm{I}=V$. bithynica $\mathrm{L}=V$. faba.

the species even if to a minimum extent in $V$. sativa and even less in $V$. bithynica. Inside the Narbonensis section, the banding pattern clearly differentiate $V$. serratifolia in comparison to the other species, which, on the contrary, shared several bands and a greater similarity is evident between $V$. johannis and $V$. byaeniscyamus.

The tandem array of $V f \mathrm{M}$ consists of 4 repetitions of a sequence which doesn't show any homology with sequences reported in EMBL database, as evidenced from Fasta alignment (PEArson and Lipman 1988). The length is invariably $60 \mathrm{bp}$, with the exception of the fourth incomplete repeat of 46 bp (Fig. 4). A+T content of VfM repeats is $53.8 \%$ and the nucleotide sequence is highly conserved among the repeats: the homology ranges from $88.33 \%$ to $95 \%$.
No typical ladder of multimers of about $60 \mathrm{bp}$ was produced in the blots of $V$. faba DNA after digestion with different restriction endonucleases (BamHI, EcoRI, TaqI, RsaI, Sau3AI, AluI which don't find any cleavage site and HinfI restriction endonuclease, which presents three cleavage sites in the sequence) and hybridization with digoxigenin-labelled VfM (Fig. 5); lack of signal was also observed after hybridization of labelled probe to the metaphase chromosomes of $V$. faba, suggesting a moderate representativeness of the sequence in the genome of field bean.

Lack of signal has been observed after hybridization of digoxigenin-labelled $V f \mathrm{M}$ to the genomic DNAs of all the species, digested with HinfI restriction endonuclease (data not shown). With the aim to study the organization of this DNA element in the genome of $V$. $f a b a$, we have analysed the genomic library at our disposal with VfM labelled probe and three positive clones containing sequences homologous to VfM repeats were obtained (Fig.6).

Fig. 7 shows the alignment of the repeats (except for the incomplete repeats) of the three clones in addition to VfM and a similarity index of $80,6 \%$ was determined. In all the clones, the most conserved region was the initial one and this sequence was used as a single primer in DAMD-PCR experiments.

The DAMD-PCR (Fig. 8) profiles reveal variations among Vicia species. There are from one to four distinguishable bands, in addition to several other faint bands amplified in the different species. The number and positions of these bands depend on species and in many cases clearly discriminate among them. In particular $V$. faba presents two evident and eight faint bands, while $V$. bithynica as $V$. sativa evidence only one band, but of different molecular weight. The species of Narbonensis section present a different banding pattern not only in comparison with $V$. faba, $V$. bithynica and $V$. sativa but also if compared one to each other inside the section. Anyway, some species share more bands respect to the other species. This is the case of $V$. eristalioides and $V$. kalakhensis and V. byaeniscyamus and V. jobannis, respectively.

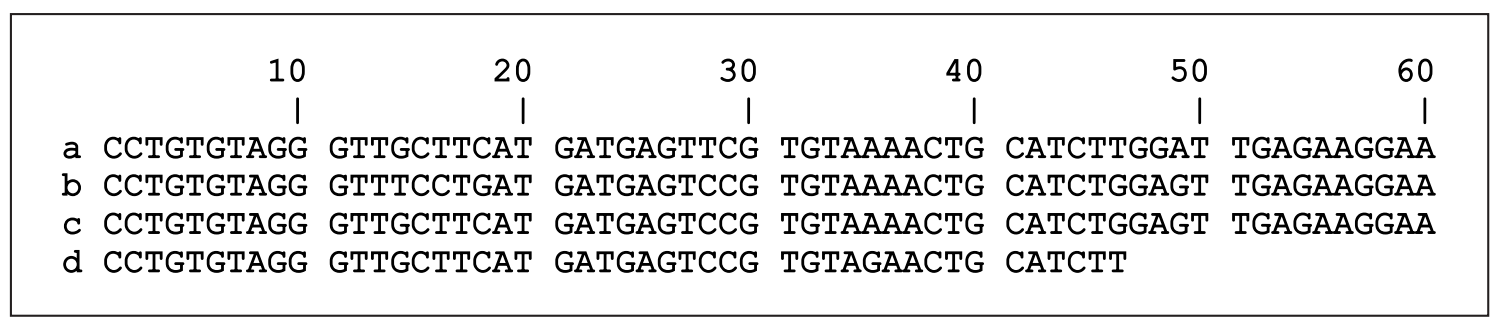

Fig. 4 - Nucleotide sequence of VfM element. The different repeats are indicated with different letters. 


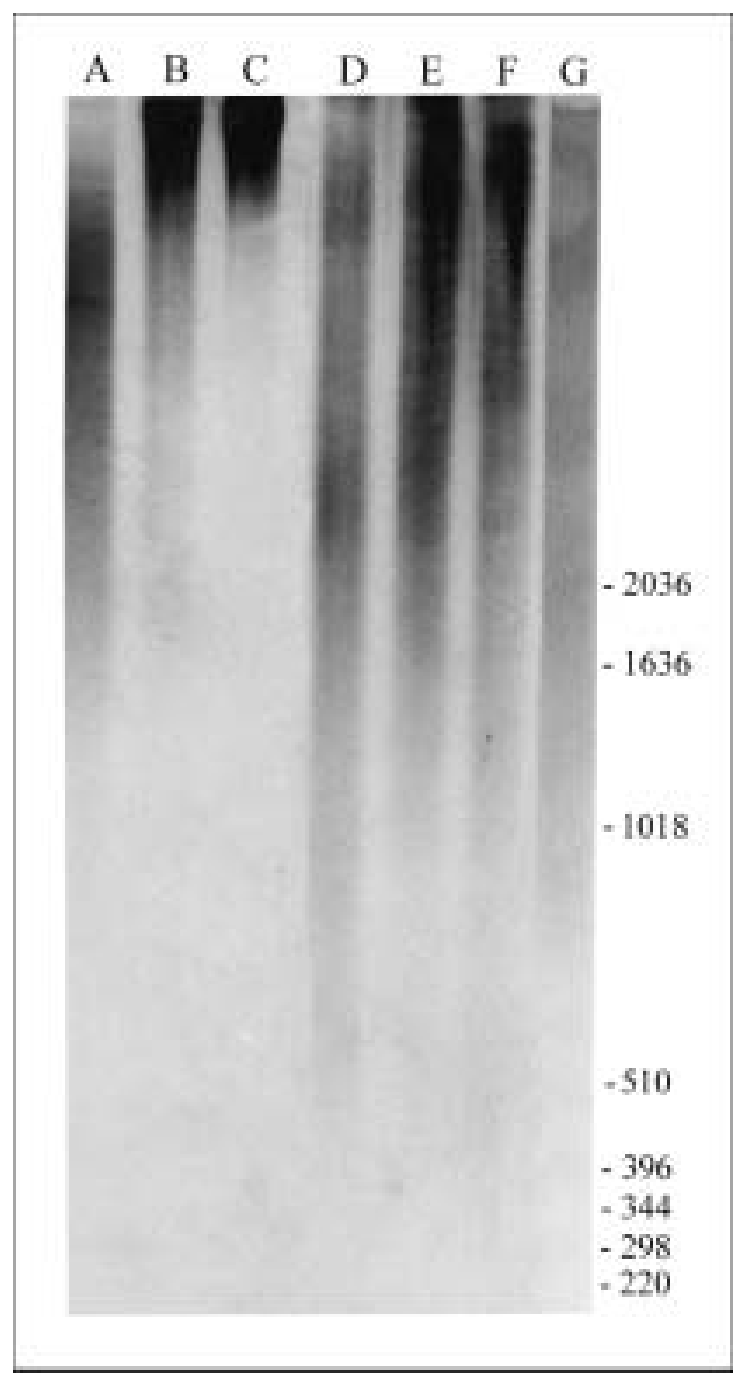

Fig. 5 - Band patterns of genomic DNA of $V$. faba digested with $\mathrm{A}=\mathrm{RsaI} ; \mathrm{B}=\mathrm{EcoRI} ; \mathrm{C}=\mathrm{BamHI} ; \mathrm{D}=\mathrm{Sau} 3 \mathrm{AI} ; \mathrm{E}=\mathrm{AluI}$; $\mathrm{F}=$ TaqI; $\mathrm{G}=$ HinfI restriction endonucleases, after Southern blot hybridization with digoxigenin-labelled VfM probe. $\mathrm{Nu}$ merals indicate molecular sizes in base pairs as determined using a 1-kb DNA ladder as a marker.

\section{DISCUSSION}

MAXTED (1993) proposed a new classification of subgenus Vicia where nine sections are present and the old Faba section was substituted by three distinct sections: Bithynicae and Faba, monospecific, and Narbonensis which contains the seven species before referred to as the Narbonensis complex. In this connection, is noteworthy that the phylogenetic data generated from the analysis of the sequences of Internal Transcribed Spacers (ITS) of rDNA and from karyomorphological data (VENORA et al. 2000), provided support for this new classification.
In this paper we report further evidence obtained by using four different DNA repeated sequences. The results obtained by studying the FokI elements in the genomes of the species belonging to the sections Faba, Bithynicae and Narbonensis, in addition to $V$. sativa, allow us to conclude that they are almost species-specific to $V$. faba. Indeed FokI elements are detectable only in $V$. narbonensis, even if to a minimum extent. Faint hybridization signal is also present in $V$. sativa, which is included in sect. Vicia of the subgenus Vicia, according to the Maxted's classification (MAxted 1993).

Analogous results are obtained by hybridizing $\mathrm{p} V f 7$ sequences on the analysed species. Indeed, strong hybridization signal is obtained on $V$. faba blots only, even if $\mathrm{p} V f \mathrm{f}$ sequences are detectable in $V$. narbonensis and $V$. sativa, but in this case the hybridization signal is stronger in $V$. sativa than in $V$. narbonensis.

Lack of hybridization to our Southern blots cannot be equated with absence of homologous sequences, however our findings may be taken as indicating different degrees of homology between sequences and then differing phylogenetic distances between species. However, V. sativa which is not included in the three sections we have analysed, shares more genomic similarity with $V$. faba than the other species.

$V f B$ elements are represented in the DNA of the species of sect. Narbonensis but to a reduced extent compared with that of $V$. faba and even less in that of $V$. sativa and of $V$. bithynica. It is noteworthy that this molecular marker discriminates also inside the Narbonensis section, showing a greater similarity between $V$. hyaeniscyamus and $V$. johannis and clearly differentiating $V$. serratifolia from the remaining species.

The fourth molecular marker, VfM, is a tandemly-arrayed AT-rich sequence, with a monomeric unit of $60 \mathrm{bp}$. The lack of typical ladder in the hybridization patterns after Southern blotting and the negative results of cytological hybridization, indicate that VfM elements are moderately represented in the genome of $V$. faba and/or they are not organized as a simple tandem arrays in $V$. faba genome, but rather in clusters dispersed throughout the genome. VfM elements are species-specific, indeed when they are used as a probe in experiments of Southern blot hybridization on all the selected species, the signal is present in the genomic DNA of $V$. faba only.

The collected results, in particular the length of the repeats and the organization in the genome prompt us to consider VfM as a minisatellite-like sequence and to use the most conserved region of the sequence as a primer in DAMD-PCR experiments. 


\section{$V f \mathbf{R} 3$}
a) CCTGgGtAgG GTTGCTTCAT AgGAGTCCGT TTAAACTACA CTAGAATTTG GAgAAgGAT
b) CCTGGGTAGg GATGCTTTAG GATGGGTTCG TGTGAAACTG CATCTGGAAA GAGAAGGAA
c) CCTGGGTAGG GTTTCTTCAT GATGAGTTCG TGTAAAACTT CATCTGGGAA GAGAAGGAA
d) CCTGgGtAgg GTTGCTTCAT GATAAATCAG TGTAAAACTT CATATGGAAA GAGAC GAA
e) CCTGGGTAGg GTTGCTTCAT GATGAGTCCA TGTAAAACTT CATATGGAAA TGTATGACAA GGAA
f) CCTGGGTAGG GTTACTTCAT

\section{VfR9}

a) CCTGgGTAGg GTTTCCTTGA TGATGAGTCT GTGTAAAACT TTCATTTTGg AAAGAAGGAA

b) CCCTGTGTAG GGTTTCTTGA TGATGAGTCC GTGTAAAACT TCATCTTGGA AAGAAGGAA

c) CCTGTGTAGg GTTTCTTTGA TGATGAGTCT GTGTAAAACT GCA

\section{VfR10}

a) CCTGTGTAGA GTTGCTTCAT GATGAGTCCG TGTAAAACTG CATCTTGGAA AGAAGGAA

b) CCTGTGTAGG GTTTCTTGAT GATGAGTCCA GTGTAAAACT TCATCTTGGA AAGAAGGAA c) CCTGTGTAGG GTTTCTTGAT GATGAGT

Fig. 6 - Nucleotide sequences of DNA fragments homologous to VfM element identified in the clones VfR3, VfR9 and VfR10. In each clone the different repeats are indicated with different letters.
$V f M b$
CCTGTGTAGGGTTTCCTGATGATGAGTCC.GTGTAAAACTG.CATCTGGAGTT . . . . GAGAAGGAA. 60
$\mathrm{V} \mathrm{Ma}$ СCTGTGTAGGGTTGCTTCATGATGAGTTC.GTGTAAAACTG.CATCTTGGATT . . . . GAGAAGGAA. 60 CCTGTGTAGGGTTGCTTCATGATGAGTCC.GTGTAAAACTG.CATCTGGAGTT . . . .GAGAAGGAA. 60
VfR9b CCTGTGTAGGGTTTCTTGATGATGAGTCC.GTGTAAAACTT.CATCTTGGAA.......AGAAGGAA. 58
VfR3a CCTGGGTAGGGTTGCTTCATGAGGAGTCC.GTGTTAAACTA. CACCTAGAATT.TGAGAGAAGGAT. 63
VfR3b CCTGGGTAGGGATGCTTTAGGATGGGTTC.GTGTGAAACTG.CATCTGGAAAT. . . GAGAAGGAA. 60
VfR3C CCTGGGTAGGGTTTCTTCATGATGAGTTC.GTGTAAAACTT.CATCTGGGAAT....GAGAAGGAA. 60
VfR3d CCTGGGTAGGGTTGCTTCATGATAAATCA. GTGTAAAACTT.CATATGGAAAA.... GAGACG.AA. . 59
VfR3e CCTGGGTAGGGTTGCTTCATGATGAGTCC.ATGTAAAACTT.CATATGGAAATGTATGACAAGGAA. 64
VfR9a CCTGGGTAGGGTTTCTTGATGATGAGTCT.GTGTAAAACTTTCATTTTGGAA......AGAAGGAAC 60
VfR10b CCTGTGTAGGGTTTCTTGATGATGAGTCCAGTGTAAAACTT.CATCTTGGAA...... AGAAGGAA. 59
VfR10a CCTGTGTAGAGTTGCTTCATGATGAGTCC. GTGTAAAACTG. CATCTTGGAA. . .... AGAAGGAA. 58
Cons. CCTG.gtAggGtT.CtT.AtgAtgagTcc.gTGTaAAACT..Cat.T.g.a..... AgAaggAa

Fig. 7 - Comparison of the different repeats of VfM, VfR3, VfR9 and VfR10 (as reported in Figs. 4 and 6) with consensus sequence where in uppercase are reported the identical bases and in lowercase the bases well conserved. Only the complete repeats are reported and hyphens represent gaps introduced to maximize homology.

This method allows us to characterize the different species, since the number and the size of the PCR fragments is generally different in the species. Our results are consistent with Maxted's classification (MAXTED 1993) since the banding patterns clearly differentiate $V$. faba, $V$. bithynica and the species of Narbonensis section.

Many reports in the literature confirm our results and Maxted's classification. Indeed Zimmiak-Przybylska and Przybylska (1995) evidenced, by the electrophoretic analysis of seed globulin, that $V$. faba was clearly different from the species of Narbonensis section. JaAska (1997), Przybylska et al. (1998) and LETH and JAASKA (2000), by isozymes analyses, showed that $V$. faba and $V$. bithynica were most distantly related to one another and to the species of sect. Narbonensis. Ротокіna et al. (1999), by RAPD analysis of genomic DNA and PCR-RFLP analysis of chloroplast genes, highlighted that $V$. faba was more closely related to $V$. bithynica than to the other spe- 


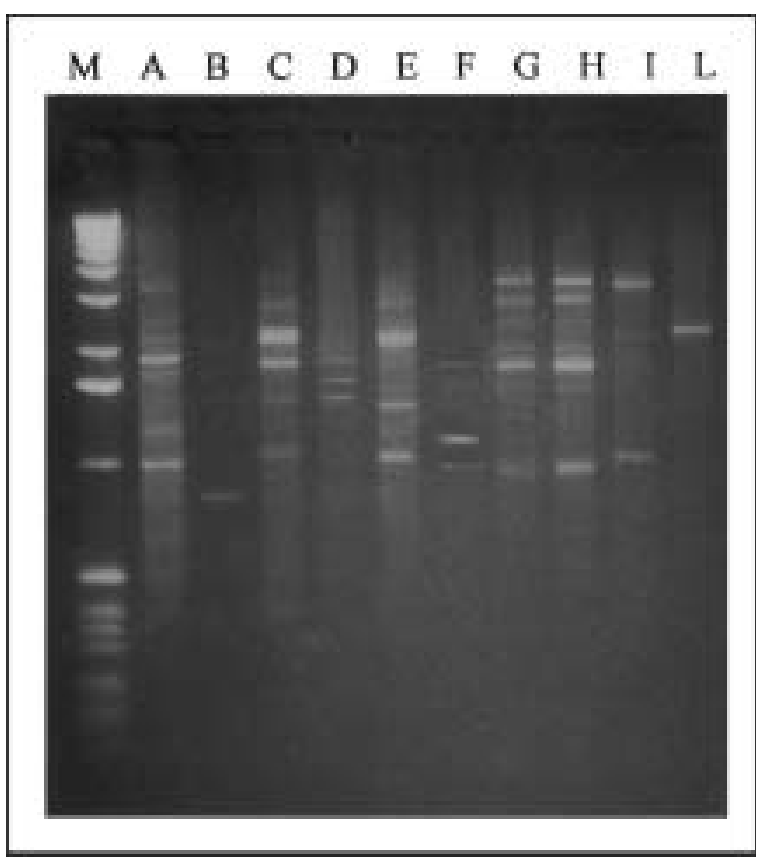

Fig. 8 - DAMD-PCR amplification of DNAs of Vicia species. $\mathrm{A}=V$. faba; $\mathrm{B}=V$. bithynica; $\mathrm{C}=V$. eristalioides $\mathrm{D}=V$. narbonensis; $\mathrm{E}=V$. kalakhensis; $\mathrm{F}=V$. galilaea $; \mathrm{G}=V$. hyaeniscyamus; $\mathrm{H}=V$. johannis; $\mathrm{I}=V$. serratifolia $\mathrm{L}=V$. sativa. $\mathrm{M}=1-\mathrm{Kb}$ ladder.

cies of sect. Narbonensis and suggested that these two species could have the same ancestors as species belonging to the Peregrinae section, as suggested by JAASKA (1997), too.

Our results also evidence that the banding patterns obtained by DAMD-PCR experiments discriminate inside this last section, showing a greater similarity between $V$. byaeniscyamus and $V$. johannis and, at less extent, between $V$. eristalioides and $V$. kalakbensis. Although it is not known if the common fragments amplified were from the same loci in the different species, it is possible to suppose that more bands in common may signify more affinity.

In this connection, it is noteworthy that the present data partially agree with the spatial representation of the karyological indices that highlighted four distinct group inside the Narbonensis section, including in the same group $V$. eristalioides and $V$. kalakbensis, while ITS analyses did not enable clarification of the phylogenetic relationships among the species of the section (VENORA et al. 2000).

Maxted (1993) subdivided sect. Narbonensis in two series: Rhombocarpae, with $V$. eristalioides only, and Narbonensis including the other species. Up today only one report confirms this subdivision of the sect. Narbonensis, indeed PRZybylska and ZIMMIAK-PRZYBYLSKA (1995), by the analysis of seed albumins, evidenced that $V$. eristalioides was a peripheral member of the sect. Narbonensis. Other reports, by isozyme analysis, have evidenced specific relationship inside the Narbonensis section: two lineages $V$. narbonensis- $V$. serratofolia and $V$. johannis- $V$. galilaea (JAAskA 1997), one lineage $V$. jobannis and V. galilaea (Przybylska et al. 1998). Potokina et al. (1999) subdivided the sect. Narbonensis in two subclusters, the former with $V$. narbonensis and $V$. serratifolia and the latter with $\mathrm{V}$. galilaea, V. johannis, $V$. byaeniscyamus and $V$. kalakhensis.

Therefore from the four markers we have used it is evident that $V$. faba, $V$. bitbynica and the species of sect. Narbonensis are three distinct taxonomic groups according to MAXTED's classification (MAxted 1993), but VfB and VfM only are useful for a discrimination inside the sect. Narbonensis.

\section{REFERENCES}

Ball P.W., 1968 - Vicia. In: T.C. Tutin, V.H. Haywood, N.A. Burges, D.M. Moore, D.H. Valentine, S.M. Walters and D.A. Webb (Eds), "Flora Europaea”, p.129-136. Cambridge University Press, Cambridge and London.

Broun P. and Tanksley S.D., 1993 - Characterization of tomato DNA clones with sequence similarity to buman minisatellites 33.6 and 33.15. Plant Molecular Biology, 23: 231-242.

Ceccarelli M., Minelli S., Maggini F. and Cionini P.G., 1995 - Genome size variation in Vicia faba. Heredity, 74: 180-187

Cremonini R., Miotto D., Api Ngu M., Tota D., Pignone D., Blangiforti S. and Venora G., 1998a - Cytology of Vicia species 5: nuclear chromatin structure, karyomorphological analysis and DNA content in newly discovered relatives of Vicia faba L.: Vicia kalakhensis Khattab, Maxted E Bisby and Vicia eristalioides Maxted. Cytologia, 63: 371-379.

Cremonini R., Ruffini Castiglione M., Venora G., Blangiforti S., Lo Savio F.P. and Pignone D., 1998b - Cytology of Vicia species 6: nuclear chromatin organization, karyomorphological analysis and DNA amount in Vicia serratifolia Jacq. Caryologia, 51: 195-205.

Frediani M., Sassoli O. and Cremonini R., 1992 Nuclear DNA characterization of two species of $V i$ cia: $V$. bitbynica $L$. and $V$. narbonensis $L$. Biologia Plantarum, 34: 335-344.

Frediani M., Gelati M. T., Maggini F., Galasso I., Minelli S., Ceccarelli M. and Cionini P.G., 1999 - A family of dispersed repeats in the genome of Vicia faba: structure, chromosomal organization, redundancy modulation and evolution. Chromosoma, 108: 317-324

Heath D.D., Iwama G.K. and Devlin R.H., 1993 PCR primed with VNTR core sequence yield speciesspecific patterns and bypervariable probes. Nucleic Acids Research, 21:5782-5785

JAASKA V., 1997 - Isoenzyme diversity and phylogenetic affinities in Vicia subgenus Vicia (Fabaceae). Genetic Research Crop Evolution, 44: 557-574. 
Jefrereys A.J. and Morton D.B., 1987 - DNA fingerprints of dogs and cats. Animal Genetic, 18: 1-15.

JefrReys A.J., Wilson V. and Thein S.L., 1985 Hypervariable "minisatellite" regions in buman DNA. Nature, 314: 67-73

Kato A., Yakura K. and Tanifuji S., 1984 - Sequence analysis of Vicia faba repeated DNA, the FokI repeat element. Nucleic Acids Research, 12: 37-48.

Kato A., Yakura K. and Tanifuji S., $1985-R e$ peated DNA sequences found in the large spacer of Vicia faba rDNA. Biochimica et Biophysica Acta, 825: 411-415.

Khatтab A.M.A., Maxted N. and Bisby F.A., 1988 - Close relatives of the Faba bean from Syria: a new species of Vicia and notes on V. byaeniscyamus (Leguminosae). Kew Bulletin, 43: 535-540.

Kupicha F.K., 1976 - The infrageneric structure of Vicia. Notes from the Royal Botanic Garden Edinburgh, 34: 287-326.

LeTH H. and JAAskA V., 2002 - Cladistic and phenetic analysis of relationships in Vicia subgenus Vicia (Fabaceae) by morphology and isozymes. Plant Systematics and Evolution, 232: 237-260.

Maggini F., Barsanti P. and Marazia T., 1978 - Individual variation in the nucleolus organizer regions in Allium cepa and A. sativum. Chromosoma, 66: 173-183.

Maggini F., Cremonini R., Zolfino C., Tucci G.F., D’Ovidio R., Delre V., DePace C., Scarascia Mugnozza G.T. and Cionini P.G., 1991 - Structure and chromosomal localization of DNA sequences related to ribosomal subrepeats in Vicia faba. Chromosoma, 100: 229-234.

Maggini F., D’Ovidio R, Gelati M.T., Frediani M., Cremonini R., Ceccarelli M., Minelli S. and Cionini P.G., 1995 - FokI DNA repeats in the genome of Vicia faba: species-specificity, structure, redundancy modulation, and nuclear organization. Genome, 38: 1255-1261.

Maxted N., 1988 - A new Vicia from Southwest Turkey. Notes from the Royal Botanic Garden Edinburgh, 45: 453-456.

Maxted N., 1993 - A phenetic investigation of Vicia L. subgenus Vicia (Leguminosae, Vicieae). Botanical Journal of Linnean Society, 111:155-182.

Maxted N., Khattab A.M.A. and Bisby F.A., 1991 - The newly discovered relatives of Vicia faba L. do little to resolve the enigma of its origin. Botanika Chronika, 10: 435-465.
Nakamura Y., Leppert M., O’ Connell P., Wolff R., Holm T., Culver M., Martin C., Fujimoto E., Hoff M., Kumlin E. and White R., 1987 Variable number of tandem repeats (VNTR) markers for buman gene mapping. Science, 235: 1616-1622.

PeArson W.R. and Lipman D.J., 1988 - Improved tools for biological sequence comparison. Proceedings of National Academy of Sciences, USA, 85: 2444-2448.

Ротokina E.K., Tomooka N., Vaughan D.A., AlexANDrova T. and Xu R.Q., I999 Â Phylogeny of Vicia subgenus Vicia (Fabaceae) based on analysis of RAPDs and RFLP of PCR amplified chloroplast genes. Genetic Research Crop Evolution, 46: 149161.

Przybylska J. and Zimniak-PrZybylska Z., 1995 Electrophoretic seed albumin patterns and species relationships in Vicia section Faba. Plant Systematics and Evolution, 198: 179-194.

Przybylska J., Zimniak-Przybylska Z . and KrajewSKI P., 1998 - Isoenzyme variation in the wild relatives of Vicia faba. Plant Systematics and Evolution, 213: 173-186.

Rees H., Cameron F.M., Hazarika M.H. and Jones G.H., 1966 - Nuclear variation between diploid angiosperms. Nature, 211: 828-830.

SOUTHERN E.M., 1975 — Detection of specific sequences among DNA fragments separated by gel electrophoresis. Journal Molecular Biology, 98: 1073-1082.

Tourmente S., Deragon J.M., Lafleuriel J., Tutois S., Pelissier T., Cuvillier C., Espagnol M.C. and PICARD G., 1994 - Characterization of minisatellites in Arabidopsis thaliana with sequence similarity to the buman minisatellite core sequence. Nucleic Acids Research, 22: 3317-3321.

Venora G., Blangiforti S., Frediani M., Maggini F., Gelati M.T., Ruffini Castiglione M. and Cremonini R., 2000 - Nuclear DNA contents, $r D$ $N A s$, chromatin organization and karyotype evolution in Faba section of the Vicia genus. Protoplasma, 213:118-125.

Winberg B.C., Zhou Z., Dallas J.F., McIntyre C.L. and Gustafson J.P., 1993 - Characterization of minisatellite sequences from Oryza sativa. Genome, 35: 978-983

Zimniak-Przybylska Z. and Przybylska J., 1995 Electrophoretic seed globulin pattern and species relationships in Vicia section Faba. Journal Applied Genetics, 36:299-312. 